\title{
Digital Education for Sustainable Development in Non-Formal Education in Germany and COVID-19-Induced Changes
}

\author{
Florian Kohler ${ }^{1,2, *}$, Alina Kuthe ${ }^{3}$, Fiona Rochholz ${ }^{1}\left(\mathbb{D}\right.$ and Alexander Siegmund ${ }^{1,2,4}$ \\ 1 Research Group for Earth Observation (rgeo), Department of Geography, Heidelberg University of Education, \\ Czernyring 22/10-12, D-69115 Heidelberg, Germany; rochholz@ph-heidelberg.de (F.R.); \\ siegmund@ph-heidelberg.de (A.S.) \\ 2 Heidelberg Center of Education for Sustainable Development, Heidelberg University of Education, \\ Bergheimer Str. 104, D-69115 Heidelberg, Germany \\ 3 Kompetenzzentrum Lehre (KoLe), Nuertingen-Geislingen University, Marktstr. 16, \\ D-72622 Nürtingen, Germany; alina.kuthe@hfwu.de \\ 4 Heidelberg Center for the Environment (HCE) \& Institute of Geography, Heidelberg University, \\ Berliner Straße 48, D-69120 Heidelberg, Germany \\ * Correspondence: f.kohler@ph-heidelberg.de
}

Citation: Kohler, F.; Kuthe, A.; Rochholz, F.; Siegmund, A. Digital Education for Sustainable Development in Non-Formal Education in Germany and COVID-19-Induced Changes. Sustainability 2022, 14, 2114. https:// doi.org/10.3390/su14042114

Academic Editors:

Antonio-Manuel Rodríguez-García, María-Natalia Campos-Soto and Juan Carlos de la Cruz-Campos

Received: 22 December 2021

Accepted: 8 February 2022

Published: 12 February 2022

Publisher's Note: MDPI stays neutral with regard to jurisdictional claims in published maps and institutional affiliations.

Copyright: (C) 2022 by the authors. Licensee MDPI, Basel, Switzerland. This article is an open access article distributed under the terms and conditions of the Creative Commons Attribution (CC BY) license (https:// creativecommons.org/licenses/by/ $4.0 /)$.

\begin{abstract}
Digital media increasingly transform daily routines as well as everyday actions and working environments, including education. Apps, games, computer programs, and social media, etc. can support and improve learning processes. The COVID-19 pandemic and the resulting restrictions of social life accelerated a shift towards the application of digital media in education as well as in distance learning. This paper answers questions about the current usage of digital media in nonformal education in Germany, especially in the context of Education for Sustainable Development (ESD). The results of a 2020 survey in Germany with 111 participants show that digital media are an integral part of non-formal education; in particular, audio and video recording and filesharing are used often. Notably, the usage of web calls and webinars has increased since the pandemic. Regarding the disadvantages of digitals formats, participants note the investment in time and effort as well as the expensive equipment needed for development. Despite being dissatisfied with existing offers, a lot of institutions have not developed their own digital education formats (yet). This indicates a possible need for further training and education of educators in non-formal ESD, enabling them to independently create digital formats. This would also contribute to the quality of digital formats, of which many were possibly developed without proper expertise.
\end{abstract}

Keywords: digital education; environmental education; global education; \#ESDfor2030; Digital Sustainability Education (DSE); pandemic

\section{Introduction}

The transformation of our everyday life towards a digitalized world as well as the widespread adoption of technologies for our tasks is shaping our current society. Advances in artificial intelligence, robotics, and augmented and virtual realities (AR/VR) allow various technologies to be included in an increasing number of processes and ranges of actions of our society (WBGU, 2019 [1]). This development does not leave the sector of education unaffected, particularly younger generations who are highly receptive to the application and advancement of digital media and who can adapt to digital transformation. In this context, digital resources such as apps or AR/VR, as well as digital courses, play an increasingly important role. This evolvement was significantly reinforced in 2020 and 2021 by the COVID-19 pandemic and the implied shift from face-to-face to distance learning formats.

Electronic Learning (e-learning) may include all learning formats facilitated through digital media and can foster cognitive skills and competencies as efficiently as conventional, 
analogue formats (Sun et al., 2008 [2]). Further advantages of e-learning include increased accessibility, as digital formats are either less or not time- and location-dependent, which means that materials and courses can easily be received by a broader audience. In this way, learning is more self-determined, self-regulated, and self-paced. However, should e-learning fail to establish a relation to the lifeworld of learners, it can lead to lesser learning motivation (Keller and Suzuki, 2004 [3]; Margaryan et al., 2015 [4]) and higher dropout-rates in learners (Park and Choi, 2009 [5]).

Digitalization of learning can have many benefits and may help to improve the learners' knowledge and ability to act, as is the aim in the new UNESCO program "ESD for 2030". Global challenges under a changing climate and their immediacy are undoubtedly apparent and are increasingly influencing our everyday lives (IPCC 2021 [6]). In 2015, the global community adopted 17 Sustainable Development Goals (SDGs), which address global and national challenges related to these key future issues. To implement these goals in society, everybody must fundamentally change the way they live, think, and act (Sterling 2010 [7]; UNESCO 2017 [8]). A special and important role in achieving the 17 SDGs is attributed to "Education for Sustainable Development" (ESD), as stated in the new UNESCO program "ESD for 2030". ESD seeks to contribute to a better understanding of the complex interrelationships of local and global action regarding the management of natural resources and the shaping of coexistence under the principles of justice and cultural diversity (Deutsche UNESCO-Kommision e.V. 2014 [9]; Rieckmann; Stoltenberg 2011 [10]).

When it comes to further social values and anchoring sustainable development in the consciousness of all people, non-formal education plays a central role. An overview of nonformal education in Germany and its development is provided by (Köller et al. [11]). The concepts of global learning and ESD first found their way into non-formal extracurricular education for children and teenagers (Rieckmann, Stoltenberg 2011 [10]). Non-formal education stakeholders were one of the main drivers in establishing ESD-related topics in schools during the UN Decade of ESD (Michelsen 2013 [12]; Grundmann 2017 [13]), helping to achieve positive learning outcomes (Butterer and Wohnig 2019 [14]).

The prospect of time- and location-independent digital learning can improve the individual learning processes in non-formal ESD and facilitate its dissemination (Beer et al. 2021 [15]). Nevertheless, hardly any data about the usage of digital formats in non-formal Education for Sustainable Development are available yet. However, to develop and improve formats or extend existing formats for non-formal education, these data are necessary. The purpose of this study is to provide information about the status quo of non-formal Education for Sustainable Development, and which topics and methods are used and addressed already. Furthermore, it provides figures and information on the role of digital media in non-formal education in Germany and how their role has changed in the context of the COVID-19 pandemic. This can and should provide an impetus for further development of non-formal education by identifying possible gaps and also by showing which areas are already well established and which can possibly serve as a model for other areas.

In this study, the following questions were addressed:

1. Who teaches Education for Sustainable Development (digitally) in the non-formal education sector in Germany?

2. Which topics are covered using digital formats in non-formal digital Education for Sustainable Development?

3. How are digital media being used in non-formal Education for Sustainable Development in Germany and how did this usage change due to COVID-19?

\section{Materials and Methods}

The study was conducted as a descriptive study. The sampling type was accessible sampling. The data were collected by means of an online questionnaire in German language using SoSci Survey (Leiner 2019 [16]). The study surveyed (1) the conditions and framework of the interviewed institution, such as number of employees, number of volunteers, and number of visitors, (2) the topics covered with digital formats and their affiliation with the 
SDGs, and (3) which media and digital tools are being used in their education programs and how their usage changed due to the pandemic.

The questionnaire was developed by the authors in 2019 and 2020 and validated in a pretest procedure during February 2020. For this purpose, the questionnaire was tested, commented on, and revised in two pretest rounds, with 12 and eight volunteers, respectively, from the target group, who did not participate in the survey later.

The questionnaire was spread among different institutions in the field of non-formal education, considering the broad context of Education for Sustainable Development (including global learning and environmental education, etc.) in Germany. Different mailing-lists and networks were used to contact as many relevant institutions as possible. The main challenge is the non-tangibility of the number of institutions in Germany which offer nonformal Education for Sustainable Development. Participants replied to the questionnaire between June 30th, 2020 and December 31st, 2020. The sample size of 111 respondents consists of around 100 (regional) institutions in Germany. It must be noted that the sample size of 111 respondents and roughly 100 institutions is unrepresentative of all non-formal education institutions in Germany, nor their composition. Considering the small number of participants and the explorative design of the study, the data analysis focuses on a descriptive analysis (Heumann et al. 2016 [17]; James et al. 2013 [18]; Eid et al. 2015 [19]. The data were analyzed using R (R Core Team 2018 [20]) and Microsoft Excel (Microsoft Corporation 2018 [21]). To ensure reliability, all qualitative analyses were conducted independently by at least two authors, then discussed and subsequently revised and adjusted. The data used can be found in the appendix to ensure better legibility of the results.

\section{Results}

In total, 412 people took and 111 completed the survey for their respective organization. The first question enquired about their organizational structure (Figure 1) and finances. Most of the results were registered associations or societies. About a quarter of the institutions are governmental organizations. Some institutions define themselves as non-governmental organizations (NGOs) or foundations and only $2 \%$ are either from the private sector or church-run. The remaining $16 \%$ defined themselves as 'other'.

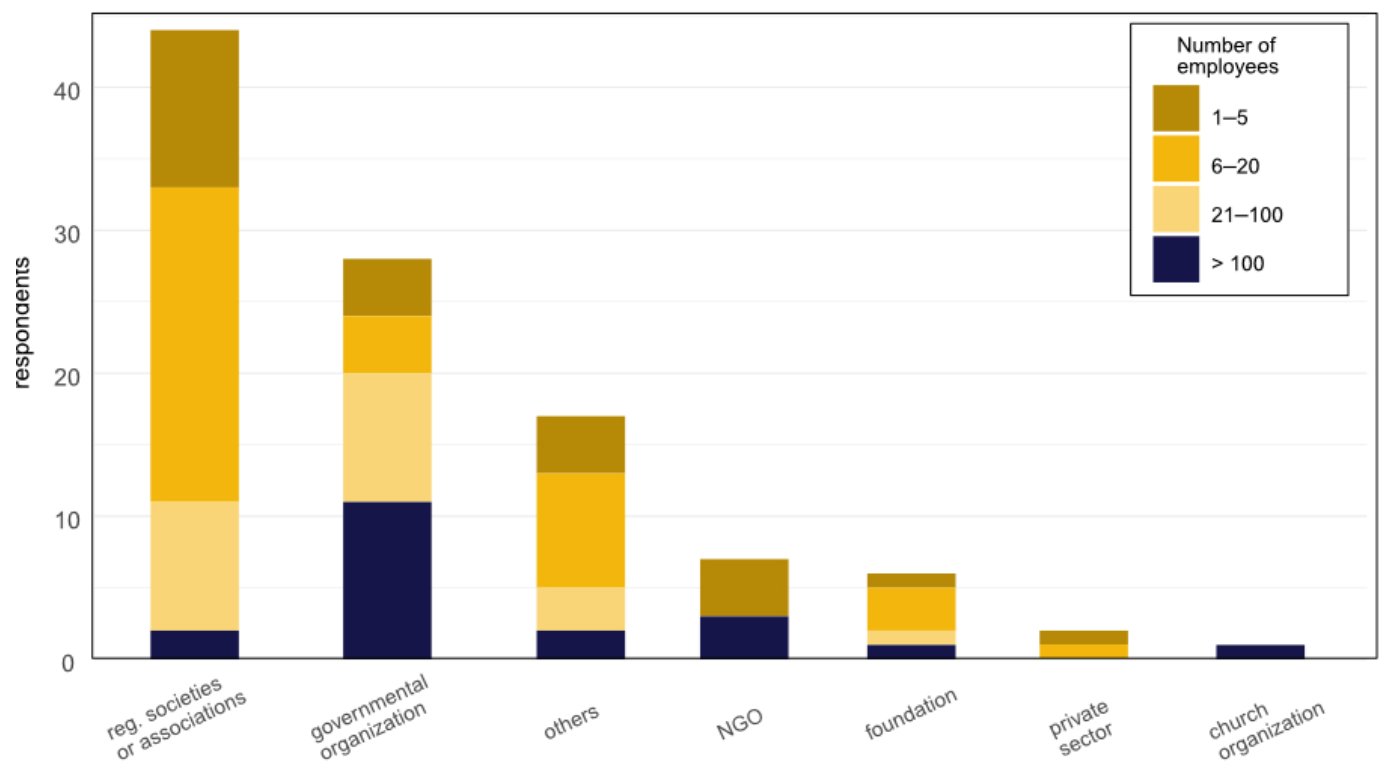

Figure 1. Surveyed institutions and number of employees.

Figure 1 shows the count of respondents for each type of organization and their respective number of employees. The corresponding data can be found in Table A1 in the backmatter of this article. 
About a quarter of the institutions have 1-5 employees, about a third have 6-20 employees, and one fifth have between 21 and 100 employees working for them. Another fifth of the institutions employ more than 100 people. Although the surveyed governmental organizations mostly employ more than 100 or at least more than 20 people, registered societies and associations mostly have 6-20 employees or fewer than five.

\subsection{Who Addresses Education for Sustainable Development (Digitally) in the Non-Formal Education Sector in Germany?}

Figure 2 shows the different target groups for educational courses-including but not limited to ESD courses-and their shares across different institutions. This shows that school classes, young adults, and children are the main target groups, while seniors, teenagers, and families are rarely addressed directly and often comprise only a small proportion within the target groups addressed.

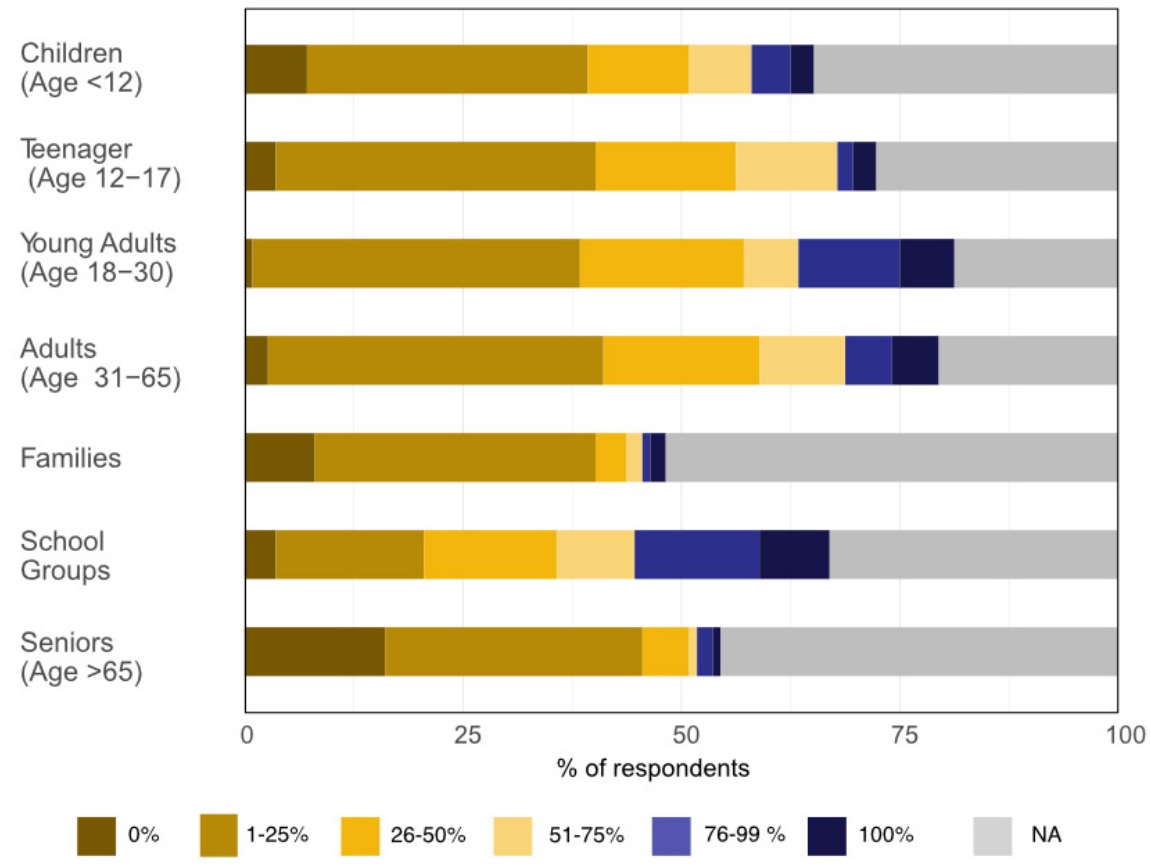

Figure 2. Target groups of the surveyed institutions for educational programs. The corresponding data can be found in Table A2 in the backmatter of this article.

Another question captures the number of visitors per year including the education programs attended. About $4 \%$ of the institutions welcome only up to 100 visitors per year, while $12 \%$ state that they host between 101 and 500 visitors, and one fifth receive between 500 and 1000 visitors. Around half of the institutions state that they welcome between 1001 and 10,000 visitors per year while only $12 \%$ host between 10,000 and 100,000 visitors per year. None of the participants host more than that.

ESD comprises more than $50 \%(51-100 \%)$ of educational programs in most of the surveyed institutions. Around $32 \%$ of the institutions state that $76-100 \%$ of their educational programs are ESD-related, while $22 \%$ claim that $51-75 \%$ of their courses are related to ESD. Therefore, the results summarize that in $54 \%$ of the institutions more than half of the visitors (51-100\%) attend a program related to ESD.

Table 1 shows that ESD-related programs are most dominant in foundations, registered associations or societies, and NGOs. In contrast, in governmental organizations, ESDrelated programs comprise a much smaller ratio in their taught programs.

It can be summarized that the institutions represented in this study are very heterogenous regarding their number of visitors and their employees, while the slight majority of the offered and booked educational programs are related to ESD. 
Table 1. Percentage (per row) of Education for Sustainable Development-related (ESD) education programs in different types of surveyed organizations.

\begin{tabular}{cccccc}
\hline Institution & $\mathbf{0 \%}$ ESD & 1-25\% ESD & 26-50\% ESD & 51-75\% ESD & 76-100\% ESD \\
\hline Registered association or society & $0(0 \%)$ & $5(11 \%)$ & $7(16 \%)$ & $13(29 \%)$ & $20(44 \%)$ \\
\hline Foundation & $0(0 \%)$ & $1(17 \%)$ & $1(17 \%)$ & $0(0 \%)$ & $4(67 \%)$ \\
\hline Governmental organization & $0(0 \%)$ & $15(52 \%)$ & $8(28 \%)$ & $2(7 \%)$ & $4(14 \%)$ \\
\hline Private sector & $0(0 \%)$ & $0(0 \%)$ & $1(50 \%)$ & $0(0 \%)$ & $1(50 \%)$ \\
\hline Non-governmental organization & $0(0 \%)$ & $2(29 \%)$ & $1(14 \%)$ & $2(29 \%)$ & $2(29 \%)$ \\
\hline Church organization & $0(0 \%)$ & $1(50 \%)$ & $0(0 \%)$ & $0(0 \%)$ & $1(50 \%)$ \\
\hline Other & $0(0 \%)$ & $4(24 \%)$ & $1(6 \%)$ & $2(12 \%)$ & $10(59 \%)$ \\
\hline
\end{tabular}

3.2. Which Topics - Corresponding to Which SDGs-Are Being Taught with Digital Formats in Non-Formal Education for Sustainable Development?

Educational topics taught in the respondents' digital courses cover a broad range. To enhance the visibility and understanding of the covered topics, they were each assigned to the five P's of sustainability (United Nations 2015): People, Planet, Prosperity, Peace, and Partnership, wherein the 17 SDGs were grouped (see Table 2). About a fifth of the 229 topics mentioned are comprehensive, meaning they cover two or more P's and therefore are not clearly classifiable. About a fifth of the topics taught can be assigned to the six SDGs grouped in the category People. Nearly half of the topics can be attributed to the category Planet, which consists of five SDGs. A small number of topics were assigned to Prosperity, which consists of four SDGs. Although there were not any topics attributed to the category Peace (one SDG), we assigned some to Partnership (one SDG).

Table 2. Topics taught in digital Education for Sustainable Development, classified into the " 5 P's of sustainability". The coding guidelines for the evaluation of these data can be found in Table A3 in the backmatter of this article.

\begin{tabular}{|c|c|c|}
\hline $\begin{array}{c}\text { Category } \\
\text { (Five P's of Sustainability) }\end{array}$ & Sustainable Development Goals & $\begin{array}{l}\text { Number of } \\
\text { Topics }(\%)\end{array}$ \\
\hline People & $\begin{array}{c}\text { No Poverty (1) } \\
\text { Zero Hunger (2) } \\
\text { Good Health and Well-Being (3) } \\
\text { Quality Education (4) } \\
\text { Gender Equality (5) }\end{array}$ & $51(22 \%)$ \\
\hline Planet & $\begin{array}{c}\text { Clean Water and Sanitation (6) Responsible } \\
\text { Consumption and Production (12) } \\
\text { Climate Action (13) } \\
\text { Life Below Water (14) } \\
\text { Life on Land (15) }\end{array}$ & $111(48 \%)$ \\
\hline Prosperity & $\begin{array}{c}\text { Affordable and Clean Energy (7) } \\
\text { Decent Work and Economic Growth (8) } \\
\text { Industry, Innovation, and Infrastructure (9) } \\
\text { Reduced Inequalities (10) } \\
\text { Sustainable Cities and Communities (11) }\end{array}$ & $15(7 \%)$ \\
\hline Peace & Peace, Justice, and Strong Institutions (16) & $0(0 \%)$ \\
\hline Partnership & Partnerships for the Goals (17) & $11(5 \%)$ \\
\hline $\begin{array}{c}\text { Not classifiable } \\
\text { or multiple categories }\end{array}$ & - & $41(18 \%)$ \\
\hline
\end{tabular}

Recapitulating, nearly half of the topics covered digitally can be assigned to the category Planet, which consists of five SDGs, while the next in size category, People, comprises about one fifth. 
3.3. How Is Digital Media Being Used in Non-Formal Education for Sustainable Development in Germany and How Did It Change Due to COVID-19?

The usage of digital media has significantly increased with COVID-19. About 78\% of the respondents state that the share of digital media in their learning programs increased due to the pandemic, while $8 \%$ started using digital media only due to COVID-19. Only a few institutions reported no change $(10 \%)$ or even a reduction $(4 \%)$ in their usage of digital media.

Figure 3 shows the different arguments towards using digital formats in non-formal ESD.

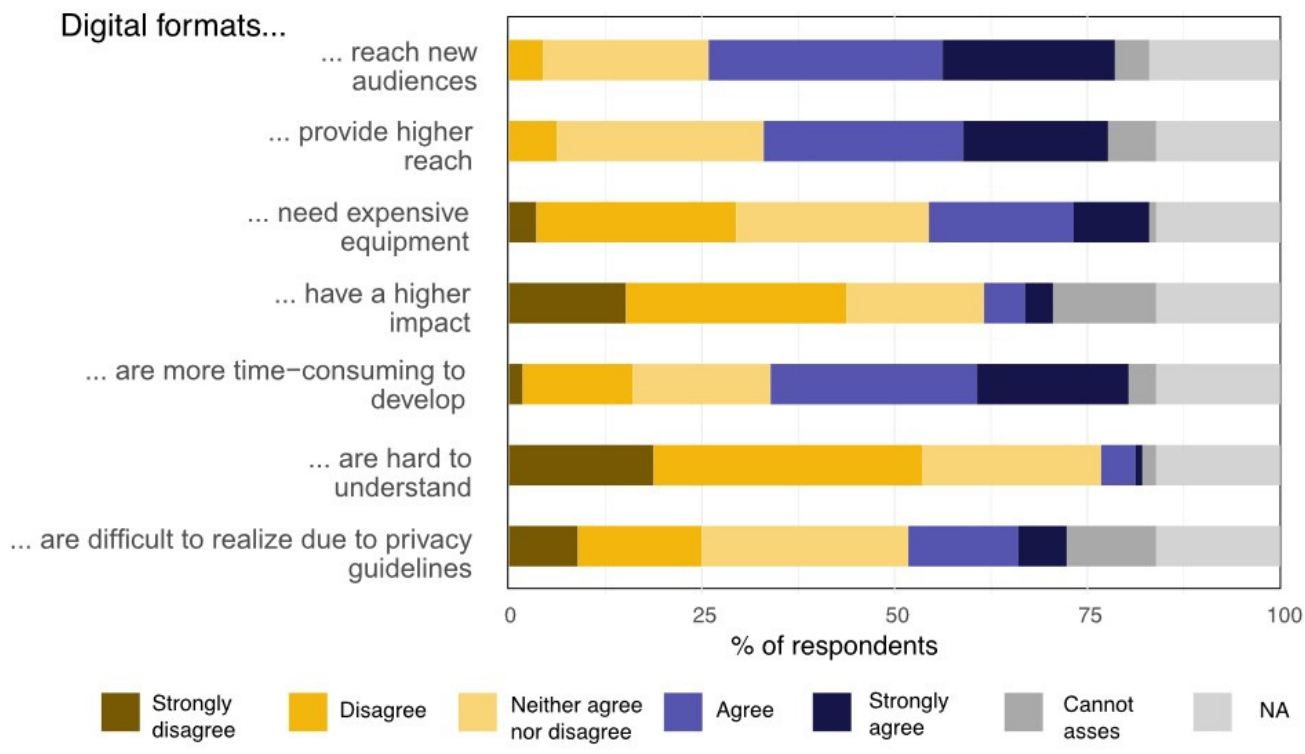

Figure 3. Reasons both for and against the usage of digital formats in non-formal Education for Sustainable Development in surveyed institutions. The corresponding data can be found in Table A4 in the backmatter of this article.

Nearly half of the respondents think that translating their analogue formats into digital formats is too time consuming. About $21 \%$ think that privacy guidelines are a big hindrance. There is little consensus about the expenses of creating digital formats. There is hardly any gap between those who think it is expensive (29\%) and those who think it is inexpensive (30\%). More than half do not consider digital formats as too complicated or hard to understand, while $45 \%$ agree that these formats increase the number of feasible participants of educational programs, and 53\% state that they can reach entirely new audiences with digital formats. Nearly half (44\%) do not agree that they have a higher impact than analog formats while only $9 \%$ do agree.

About a quarter of respondents are rather satisfied with the availability of freely available digital formats for ESD, while one sixth are discontent, and more than a third are undecided. More than half of the respondents state that they have developed digital formats while nearly a third have not. There is no visible difference in the synchronicity of the self-developed digital courses: $52 \%$ are synchronous while $48 \%$ are asynchronous. Synchronicity refers to the time of delivery; synchronous courses are taught live, in real time, and are therefore time-bound and dependent on an instructor. Asynchronous formats on the other hand can be delivered and received on-demand, independent of instructors. The coding guidelines for the evaluation of these data can be found in Table A5 in the backmatter of this article.

Figure 4 shows that in nearly half of the institutions, their self-developed digital formats comprise less than $50 \%$ of their overall educational programs, while this figure is only just over $50 \%$ for less than a tenth of the institutions. Self-developed digital resources comprise more than $50 \%$ of the overall digital formats related to ESD in slightly more 
than a tenth of the institutions, while this figure is less than half in over a third of the surveyed institutions.

What is the share of your own digital offers (developed by you) ...

... of the entirety of your learning formats

... of the entirety of your digital learning formats

of the entirety of your digital learning formats related to ESD

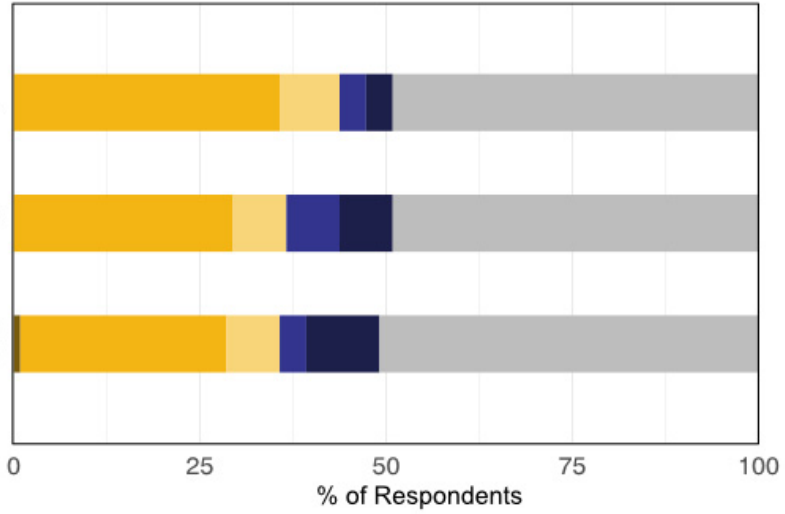

\begin{tabular}{l|l|l|l|l|l|}
\hline 0 & $1-25 \%$ & $26-50 \%$ & $51-75 \%$ & $76-100 \%$ & NA
\end{tabular}

Figure 4. Share of digital formats in educational programs from surveyed institutions. The corresponding data can be found in Table A6 in the backmatter of this article.

Figure 5 lists the various formats of digital media used by the respondents. The formats used most are audio and video recordings, filesharing, web calls, social media, and webinars. Although social media, filesharing, and audio and video recordings were mostly already used before the pandemic, usage of formats such as webinars and web calls generally increased in most institutions since the pandemic started.

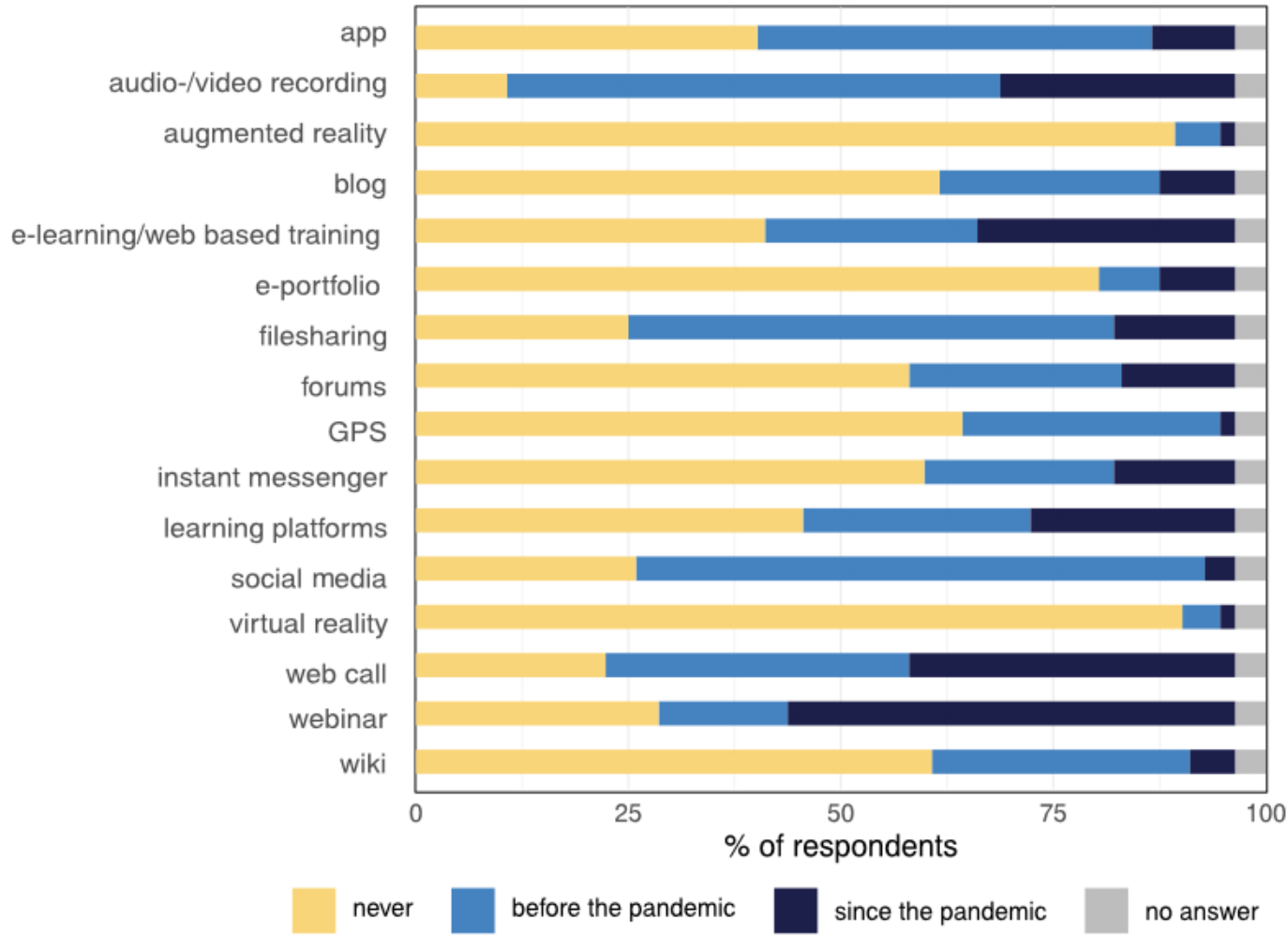

Figure 5. Digital formats used by the surveyed institutions. In each case, the possible answers were (yellow) never, (light blue) before the pandemic, (dark blue) since the pandemic, and the last column marks (grey) no answer. The corresponding data can be found in Table A7 in the backmatter of this article. 
Although learning platforms were already used by the respondents before the pandemic, their utilization doubled with the pandemic. Similar developments can be observed for e-learning and web-based training. Apps are widely employed in non-formal teaching. However, their usage did not increase much with the pandemic. Instant messengers, wikis, GPS, forums, and blogs are not widely adopted. Although the usage of wikis, GPS, and blogs did not increase due to the pandemic, instant messaging and forums saw a pandemicinduced rise. AR, VR, and e-portfolios are the least used formats; even the pandemic did not induce a sizeable increase.

\section{Discussion}

Rather than claiming to represent the totality of stakeholders involved in non-formal ESD in Germany nor their composition, this study aims to give some insights into the current situation of (digital) ESD in non-formal education. In particular, the pandemicinduced changes in education that led to an increase in the usage of digital formats. Our results thoroughly answer the first research question and show that mostly registered associations or societies along with governmental organizations (GOs) teach (digital) ESD. Nonetheless, ESD comprises a larger part of the educational portfolio in reg. associations and societies compared to GOs and others. It must be considered though, that most respondents of this survey where either from reg. associations and societies $(42 \%)$ or GOs $(26 \%)$, therefore the results might not be conclusive.

Only about $25 \%$ of respondents were happy with the already available digital formats for ESD, and therefore more than half of the institutions have developed their own digital content, while only a third have not. More than half of the respondents state that they achieve a higher coverage with digital media and accomplish the acquisition of new audiences with it. About half think that creating digital content is too effort-intensive. A third are deterred by high financial expenses and only a fifth see privacy guidelines as the main issue.

The combination of topics being taught digitally by non-formal ESD educators is centered on planetary themes, consisting of environment-related topics (48\%). This answer to the second research question is to be expected because ESD emerged from different educational concepts, one of the most widespread being Environmental Education (Overwien 2014 [22]). Therefore, sustainability is often misinterpreted as ecological sustainability (Lockley, John/Jarrath, Martin 2013 [23]). Furthermore, considering the authors' institutional networks, environment-related institutions were probably unconsciously predilected. However, Environmental Education merely covers the most wide-spread ecology-related educational concept. There are far more educational concepts which have merged into ESD, global learning being one of them (Schreiber 2012 [24], Asbrand/Scheunpflug 2014 [25]). Although topics related to People —one of the five P's of sustainability-were also being addressed frequently (22\%), topics related to Prosperity $(7 \%)$, Partnerships $(5 \%)$, and Peace $(0 \%)$ were not addressed quite as often.

Furthermore, our results answer the third research question and show that digital formats have found their way into non-formal Education for Sustainable Development, which has been accelerated due to the COVID-19 pandemic. Most institutions (78\%) have increased their usage of digital tools since the pandemic started. Some institutions ( $8 \%$ ) even launched their first digital courses due to the pandemic. In total, most of the institutions $(86 \%)$ increased their usage of digital media. Only a minority did not increase $(10 \%)$ their usage for non-formal ESD, and $4 \%$ even decreased their usage. The huge pandemic-induced increase in the usage of digital formats is above all seen in synchronous formats such as webinars and web calls, and asynchronous formats such as learning platforms, e-learning, and web-based trainings.

\section{Conclusions}

The observations of this study show the importance of digital media in non-formal education and its increased usage during the times of the pandemic. However, they reveal 
a lack of knowledge concerning creation and deployment of digital formats, leading to their restricted application in non-formal education.

The survey was concluded on 31st of December 2020, hence this study can only reflect the early stages of the pandemic. At that time most people thought or hoped that the pandemic would be over sooner rather than later. Therefore, we strongly assume that more institutions have started digitalizing their programs by now and that the proportion of digital formats and their variety has further increased throughout the pandemic.

Despite this, our results suggest that most institutions and educators in non-formal ESD will return to their face-to-face formats, indicated by the small share of $10 \%$ of respondents who think that digital formats have a higher impact. A return to face-to-face-formats is to be expected, given that ESD aims to give real-world experiences for learners in their own local or regional environment to understand global processes and the conflicting goals of sustainable development. However, positive experiences and learning success during the past two years might encourage institutions and instructors to include digital formats at least as a complementary form of teaching. After all, most respondents see advantages in using digital formats, such as reaching new audiences and increasing the number of participants in their courses or programs.

The survey reveals a discrepancy between preparedness to create own digital formats and the satisfaction with freely available digital formats and contents. Most surveyed institutions have not developed their own formats because there are too many obstacles, be it expertise, expenses, or guidelines. This observation indicates a glaring need for further training and education of educators in non-formal ESD to enable them to independently create digital formats. Target-group specific trainings for institutions missing guidance on (digital) ESD should be created to support the institutions; a possible format is exchange programs between organizations to share skills, approaches, and platforms for implementing digital ESD. Not only would this support those who have developed digital formats but feel the necessity to improve them, but it would also increase the reach of ESD in non-formal educational institutions.

Our study results highlight various gaps, which can be addressed by non-formal educators when improving existing or future educational programs, especially regarding the topics conveyed and the (digital) formats used. Surveyed institutions state that the topics covered are mainly associated with the five P's category Planet. It is particularly important to emphasize topics belonging to the other five P's within ESD while raising awareness within institutions covering those topics that they are contributors to and part of ESD. This can help spread the application of ESD to other institutions, which currently apply ESD to only a small extent. Expansion of applied digital formats to a large range of applications or newer technologies such as AR and VR, which have yet to be fully adopted in non-formal ESD, can reduce the limits of usability and simultaneously enthuse learners with the educational programs.

Nevertheless, the suggestions this survey can offer for the improvement of digital non-formal education are strongly restricted to the range of surveyed institutions addressed. In order to broaden the knowledge about existing non-formal education programs, it would be exciting to compare international progress and conduct similar studies in other countries, in order for different approaches and expertise levels to benefit from each other. Moreover, further studies in Germany should more closely examine which topics are preferentially addressed digitally in non-formal ESD and how they are implemented using digital formats. In order to further improve digital non-formal ESD, it is worthwhile to focus on the target groups of non-formal ESD and their interests and needs, such as topics addressed and the implementation of digital formats in teaching formats. Of particular interest for the learning outcome is the evaluation of the various digital formats in order to compare them to analog formats regarding their impact on learners' competencies. If standards for learners' competencies can be met in high quality digital formats, both the range and status of digital non-formal ESD are likely to grow. 
Overall, these approaches can contribute in a successful way to advancing the establishment of Education for Sustainable Development and to promote the sustainable development of our society in the long-term.

Author Contributions: Conceptualization, F.K. and A.K.; methodology, F.K. and A.K.; SoSci Survey, F.K. and A.K.; formal analysis, A.K., F.K. and F.R.; data visualization, F.R.; investigation, F.K. and A.K.; data curation, A.K., F.K. and F.R.; writing — original draft preparation, F.K. and A.K.; writing-review and editing, F.K., A.K., F.R. and A.S.; supervision, A.S. All authors have read and agreed to the published version of the manuscript.

Funding: This research received no external funding.

Institutional Review Board Statement: Not applicable.

Informed Consent Statement: Informed consent was obtained from all subjects involved in the study.

Data Availability Statement: The data that support the findings of this study are available from the corresponding author, upon reasonable request.

Acknowledgments: We thank Ingmar Mundt who helped to conceive the idea for this study and the survey, and all the respondents who took the time to contribute to the success of this study.

Conflicts of Interest: The authors declare no conflict of interest.

\section{Appendix A}

Table A1. Surveyed institutions sorted into organizational forms with their respective number of employees.

\begin{tabular}{|c|c|c|c|c|}
\hline Institutions & $\begin{array}{l}\text { Number of } \\
\text { Employees }\end{array}$ & Respondents & $\begin{array}{l}\text { Number of } \\
\text { Employees }\end{array}$ & Respondents \\
\hline $\begin{array}{l}\text { Registered } \\
\text { associations } \\
\text { or societies }\end{array}$ & $0-5$ & 11 & 21-100 & 9 \\
\hline $\begin{array}{c}\text { Governmental } \\
\text { organization }\end{array}$ & $0-5$ & 4 & 21-100 & 9 \\
\hline NGOs & $0-5$ & 4 & $21-100$ & 0 \\
\hline Church organization & $0-5$ & 0 & $21-100$ & 0 \\
\hline Foundation & $0-5$ & 1 & $21-100$ & 1 \\
\hline Private sector & $0-5$ & 1 & $21-100$ & 0 \\
\hline Others & $0-5$ & 4 & $21-100$ & 3 \\
\hline $\begin{array}{l}\text { Registered } \\
\text { associations } \\
\text { or societies }\end{array}$ & $6-20$ & 22 & $>100$ & 2 \\
\hline $\begin{array}{c}\text { Governmental } \\
\text { organization }\end{array}$ & $6-20$ & 4 & $>100$ & 11 \\
\hline NGOs & $6-20$ & 0 & $>100$ & 3 \\
\hline Church organization & $6-20$ & 0 & $>100$ & 1 \\
\hline Foundation & $6-20$ & 3 & $>100$ & 1 \\
\hline Private sector & $6-20$ & 1 & $>100$ & 0 \\
\hline Others & $6-20$ & 8 & $>100$ & 2 \\
\hline
\end{tabular}


Table A2. Target groups of surveyed institutions for educational programs.

\begin{tabular}{|c|c|c|}
\hline Answer & Target Group & $\%$ of Respondents \\
\hline $0 \%$ & Children (Age < 12) & 7.14 \\
\hline $0 \%$ & Teenager (Age 12-17) & 3.57 \\
\hline $0 \%$ & Young Adults (Age 18-30) & 0.89 \\
\hline $0 \%$ & Adults (Age 31-65) & 2.68 \\
\hline $0 \%$ & Families & 8.04 \\
\hline $0 \%$ & School Classes & 3.57 \\
\hline $0 \%$ & Seniors (Age > 65) & 16.07 \\
\hline $1-25 \%$ & Children (Age < 12) & 32.14 \\
\hline $1-25 \%$ & Teenager (Age 12-17) & 36.61 \\
\hline $1-25 \%$ & Young Adults (Age 18-30) & 37.50 \\
\hline $1-25 \%$ & Adults (Age 31-65) & 38.39 \\
\hline $1-25 \%$ & Families & 32.14 \\
\hline $1-25 \%$ & School Classes & 16.96 \\
\hline $1-25 \%$ & Seniors (Age > 65) & 29.46 \\
\hline $26-50 \%$ & Children (Age < 12) & 11.61 \\
\hline $26-50 \%$ & Teenager (Age 12-17) & 16.07 \\
\hline $26-50 \%$ & Young Adults (Age 18-30) & 18.75 \\
\hline $26-50 \%$ & Adults (Age 31-65) & 17.86 \\
\hline $26-50 \%$ & Families & 3.57 \\
\hline $26-50 \%$ & School Classes & 15.18 \\
\hline $26-50 \%$ & Seniors (Age > 65) & 5.36 \\
\hline $51-75 \%$ & Children (Age < 12) & 7.14 \\
\hline $51-75 \%$ & Teenager (Age 12-17) & 11.61 \\
\hline $51-75 \%$ & Young Adults (Age 18-30) & 6.25 \\
\hline $51-75 \%$ & Adults (Age 31-65) & 9.82 \\
\hline $51-75 \%$ & Families & 1.79 \\
\hline $51-75 \%$ & School Classes & 8.93 \\
\hline $51-75 \%$ & Seniors (Age > 65) & 0.89 \\
\hline $76-99 \%$ & Children (Age < 12) & 4.46 \\
\hline $76-99 \%$ & Teenager (Age 12-17) & 1.79 \\
\hline $76-99 \%$ & Young Adults (Age 18-30) & 11.61 \\
\hline $76-99 \%$ & Adults (Age 31-65) & 5.36 \\
\hline $76-99 \%$ & Families & 0.89 \\
\hline $76-99 \%$ & School Classes & 14.29 \\
\hline $76-99 \%$ & Seniors (Age > 65) & 1.79 \\
\hline $100 \%$ & Children $($ Age < 12) & 2.68 \\
\hline $100 \%$ & Teenager (Age 12-17) & 2.68 \\
\hline $100 \%$ & Young Adults (Age 18-30) & 6.25 \\
\hline $100 \%$ & Adults (Age 31-65) & 5.36 \\
\hline $100 \%$ & Families & 1.79 \\
\hline $100 \%$ & School Classes & 8.04 \\
\hline
\end{tabular}


Table A2. Cont.

\begin{tabular}{ccc}
\hline Answer & Target Group & \% of Respondents \\
\hline $100 \%$ & Seniors (Age $>65)$ & 0.89 \\
\hline NA & Children (Age $<12)$ & 34.82 \\
\hline NA & Teenager (Age 12-17) & 27.68 \\
\hline NA & Young Adults (Age 18-30) & 18.75 \\
\hline NA & Adults (Age 31-65) & 20.54 \\
\hline NA & Families & 51.79 \\
\hline NA & School Classes & 33.04 \\
\hline NA & Seniors (Age $>65)$ & 45.54 \\
\hline
\end{tabular}

Table A3. Coding guidelines for digitally taught topics I surveyed institutions. Examples were translated.

\begin{tabular}{|c|c|c|c|}
\hline Category & Definition & Example & Coding Rule(s) \\
\hline $\begin{array}{l}\text { Comprehensive } \\
\text { topics }\end{array}$ & $\begin{array}{l}\text { This category consists of } \\
\text { comprehensive topics which can be } \\
\text { attributed to multiple SDGs, from at } \\
\text { least } 2 \text { different categories. }\end{array}$ & $\begin{array}{l}\text { "SDGs" } \\
\text { "practical case examples" } \\
\text { "all important ESD topics" }\end{array}$ & $\begin{array}{l}\text { Every response which can be } \\
\text { attributed to multiple SDGs, from } \\
\text { at least } 2 \text { different categories. }\end{array}$ \\
\hline People & $\begin{array}{l}\text { This category comprises SDGs } 1 \text { (No } \\
\text { poverty), } 2 \text { (Zero hunger), } 3 \text { (Good } \\
\text { health and Well-being), } 4 \text { (Quality } \\
\text { education), and } 5 \text { (Gender Equality). }\end{array}$ & $\begin{array}{l}\text { "human rights" } \\
\text { "social justice" }\end{array}$ & $\begin{array}{l}\text { Every response which can clearly } \\
\text { be attributed (mainly) to one or } \\
\text { multiple SDGs from the ones } \\
\text { listed in the definition on the } \\
\text { left (1-5). }\end{array}$ \\
\hline Planet & $\begin{array}{l}\text { This category comprises SDGs } 6 \text { (Clean } \\
\text { Water and Sanitation), } 12 \text { (Responsible } \\
\text { Consumption and Production), } \\
13 \text { (Climate Action), } 14 \text { (Life Below } \\
\text { Water), and } 15 \text { (Life On Land). }\end{array}$ & $\begin{array}{l}\text { "climate protection" } \\
\text { "biodiversity" }\end{array}$ & $\begin{array}{l}\text { Every response which can clearly } \\
\text { be attributed (mainly) to one or } \\
\text { multiple SDGs from the ones } \\
\text { listed in the definition on the left } \\
\quad(6,12,13,14 \text {, and } 15) \text {. }\end{array}$ \\
\hline Prosperity & $\begin{array}{c}\text { This category comprises SDGs } \\
7 \text { (Affordable and Clean Energy), } \\
8 \text { (Decent Work and Economic Growth), } \\
9 \text { (Industry, Innovation and } \\
\text { Infrastructure), } 10 \\
\text { (Reduce Inequalities), and } 11 \\
\text { (Sustainable Cities and Communities). }\end{array}$ & $\begin{array}{c}\text { "mobility" } \\
\text { "renewable energies" }\end{array}$ & $\begin{array}{l}\text { Every response which can clearly } \\
\text { be attributed (mainly) to one or } \\
\text { multiple SDGs from the ones } \\
\text { listed in the definition on the left } \\
\qquad(7,8,9,10 \text {, and } 11) .\end{array}$ \\
\hline Peace & $\begin{array}{c}\text { This category comprises SDG } \\
16 \text { (Peace, Justice and } \\
\text { Strong Institutions). }\end{array}$ & - & $\begin{array}{l}\text { Every response which can clearly } \\
\text { be attributed (mainly) to SDG } 16 .\end{array}$ \\
\hline Partnership & $\begin{array}{l}\text { This category comprises SDG } 17 \\
\text { (Partnerships for the Goals). }\end{array}$ & "global partnerships" & $\begin{array}{l}\text { Every response which can clearly } \\
\text { be attributed (mainly) to SDG } 17 .\end{array}$ \\
\hline
\end{tabular}


Table A4. Reasons both for and against the usage of digital formats in non-formal Education for Sustainable Development in surveyed institutions.

\begin{tabular}{|c|c|c|}
\hline Answers & Digital Formats ... & $\%$ of Respondents \\
\hline Strongly disagree & ... are more time-consuming to develop & 1.79 \\
\hline$\ldots$ & $\ldots$ are hard to understand & 18.75 \\
\hline$\ldots$ & ... need expensive equipment & 3.57 \\
\hline$\ldots$ & ... provide higher reach & 0.00 \\
\hline$\ldots$ & ... reach new audiences & 0.00 \\
\hline$\ldots$ & ... have a higher impact & 15.18 \\
\hline$\ldots$ & $\ldots$ are difficult to realize due to privacy guidelines & 8.93 \\
\hline Disagree & $\ldots$ are more time-consuming to develop & 14.29 \\
\hline$\ldots$ & $\ldots$ are hard to understand & 34.82 \\
\hline$\ldots$ & ... need expensive equipment & 25.89 \\
\hline$\ldots$ & ... provide higher reach & 6.25 \\
\hline$\ldots$ & ... reach new audiences & 4.46 \\
\hline$\ldots$ & ... have a higher impact & 28.57 \\
\hline$\ldots$ & $\ldots$ are difficult to realize due to privacy guidelines & 16.07 \\
\hline neither & $\ldots$ are more time-consuming to develop & 17.86 \\
\hline$\ldots$ & $\ldots$ are hard to understand & 23.21 \\
\hline$\ldots$ & ... need expensive equipment & $\ldots$ \\
\hline$\ldots$ & ... provide higher reach & 26.79 \\
\hline$\ldots$ & ... reach new audiences & 21.43 \\
\hline$\ldots$ & ... have a higher impact & 17.86 \\
\hline$\ldots$ & $\ldots$ are difficult to realize due to privacy guidelines & 26.79 \\
\hline Agree & $\ldots$ are more time-consuming to develop & 26.79 \\
\hline$\ldots$ & $\ldots$ are hard to understand & 4.46 \\
\hline$\ldots$ & ... need expensive equipment & 18.75 \\
\hline$\ldots$ & ... provide higher reach & 25.89 \\
\hline$\ldots$ & ... reach new audiences & 30.36 \\
\hline$\ldots$ & ... have a higher impact & 5.36 \\
\hline$\ldots$ & ... are difficult to realize due to privacy guidelines & 14.29 \\
\hline Strongly agree & $\ldots$ are more time-consuming to develop & 19.64 \\
\hline$\ldots$ & $\ldots$ are hard to understand & 0.89 \\
\hline$\ldots$ & ... need expensive equipment & 9.82 \\
\hline$\ldots$ & ... provide higher reach & 18.75 \\
\hline$\ldots$ & ... reach new audiences & 22.32 \\
\hline$\ldots$ & ... have a higher impact & 3.57 \\
\hline$\ldots$ & ... are difficult to realize due to privacy guidelines & 6.25 \\
\hline Neither agree nor disagree & $\ldots$ are more time-consuming to develop & 3.57 \\
\hline$\ldots$ & $\ldots$ are hard to understand & 1.79 \\
\hline$\ldots$ & ... need expensive equipment & 0.89 \\
\hline$\ldots$ & ... provide higher reach & 6.25 \\
\hline$\ldots$ & ... reach new audiences & 4.46 \\
\hline$\ldots$ & ... have a higher impact & 13.39 \\
\hline$\ldots$ & $\ldots$ are difficult to realize due to privacy guidelines & 11.61 \\
\hline NA & $\ldots$ are more time-consuming to develop & 16.07 \\
\hline$\ldots$ & $\ldots$ are hard to understand & 16.07 \\
\hline$\ldots$ & ... need expensive equipment & 16.07 \\
\hline$\ldots$ & ... provide higher reach & 16.07 \\
\hline$\ldots$ & ... reach new audiences & 16.96 \\
\hline$\ldots$ & ... have a higher impact & 16.07 \\
\hline$\ldots$ & $\ldots$ are difficult to realize due to privacy guidelines & 16.07 \\
\hline
\end{tabular}


Table A5. Coding guidelines for the synchronicity of taught courses. Examples were translated where necessary.

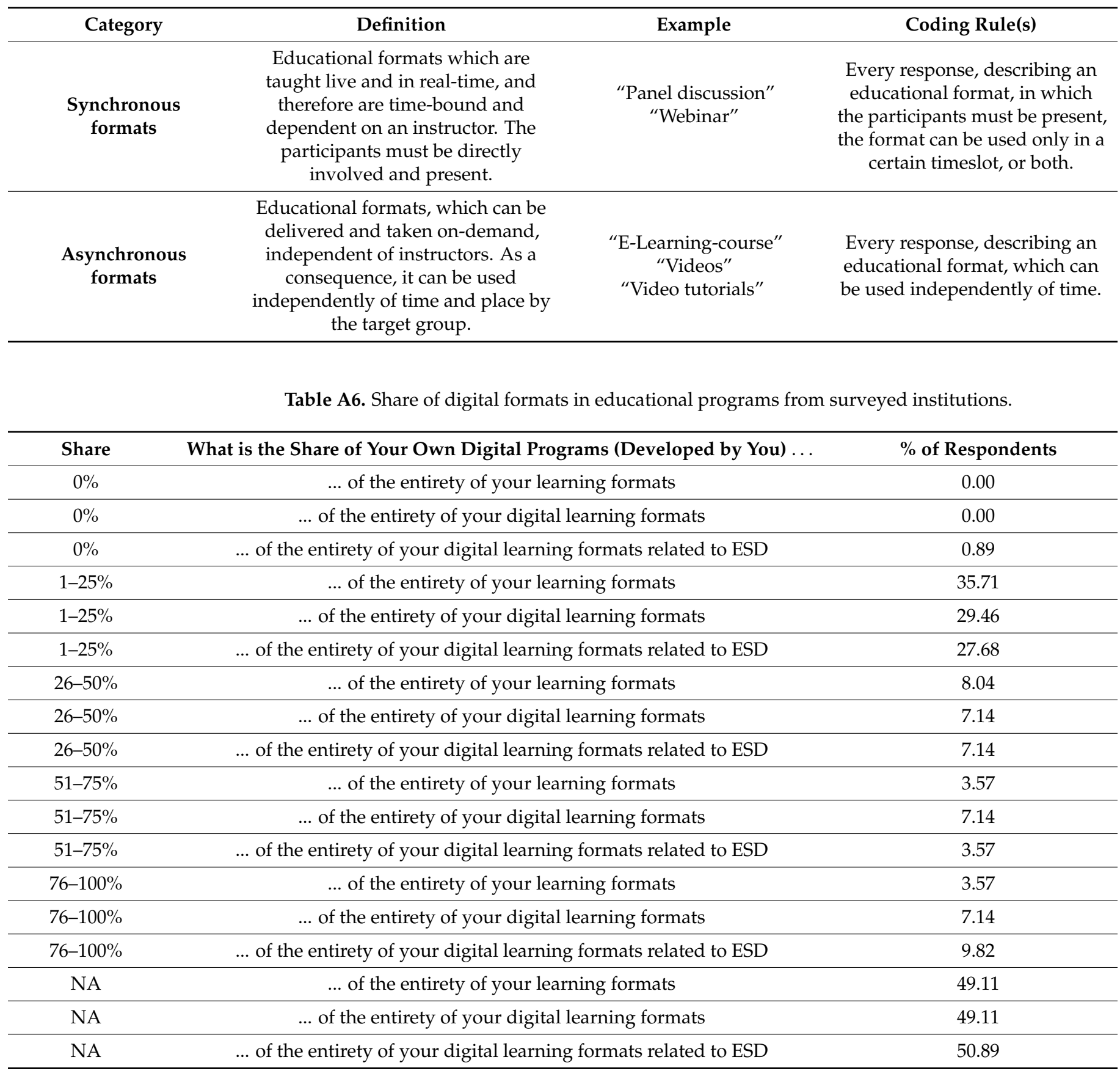


Table A7. Reasons both for and against the usage of digital formats in non-formal Education for Sustainable Development in surveyed institutions.

\begin{tabular}{|c|c|c|}
\hline Answer & Format & $\%$ of Respondents \\
\hline Before the pandemic & app & 46.43 \\
\hline ... & audio and video recording & 58.04 \\
\hline ... & augmented reality & 5.36 \\
\hline$\ldots$ & blog & 25.89 \\
\hline$\cdots$ & $\begin{array}{l}\text { e-learning and web-based } \\
\text { training }\end{array}$ & 25.00 \\
\hline$\ldots$ & e-portfolio & 7.14 \\
\hline ... & filesharing & 57.14 \\
\hline$\ldots$ & forums & 25.00 \\
\hline$\ldots$ & GPS & 30.36 \\
\hline ... & instant messenger & 22.32 \\
\hline$\ldots$ & web call & 35.71 \\
\hline$\ldots$ & learning platforms & 26.79 \\
\hline$\cdots$ & social media & 66.96 \\
\hline$\ldots$ & virtual reality & 4.46 \\
\hline$\ldots$ & webinar & 15.18 \\
\hline$\ldots$ & wiki & 30.36 \\
\hline Since the pandemic & app & 9.82 \\
\hline$\ldots$ & audio and video recording & 27.68 \\
\hline$\ldots$ & augmented reality & 1.79 \\
\hline$\ldots$ & blog & 8.93 \\
\hline$\cdots$ & $\begin{array}{l}\text { e-learning and web-based } \\
\text { training }\end{array}$ & 30.36 \\
\hline$\ldots$ & e-portfolio & 8.93 \\
\hline$\ldots$ & filesharing & 14.29 \\
\hline$\ldots$ & forums & 13.39 \\
\hline$\ldots$ & GPS & 1.79 \\
\hline$\ldots$ & instant messenger & 14.29 \\
\hline$\ldots$ & web call & 38.39 \\
\hline$\ldots$ & learning platforms & 24.11 \\
\hline$\ldots$ & social media & 3.57 \\
\hline$\ldots$ & virtual reality & 1.79 \\
\hline$\ldots$ & webinar & 52.68 \\
\hline$\ldots$ & wiki & 5.36 \\
\hline
\end{tabular}


Table A7. Cont.

\begin{tabular}{|c|c|c|}
\hline Answer & Format & $\%$ of Respondents \\
\hline Never & app & 40.18 \\
\hline$\ldots$ & audio and video recording & 10.71 \\
\hline$\ldots$ & augmented reality & 89.29 \\
\hline$\ldots$ & blog & 61.61 \\
\hline$\cdots$ & $\begin{array}{l}\text { e-learning and web-based } \\
\text { training }\end{array}$ & 41.07 \\
\hline$\ldots$ & e-portfolio & 80.36 \\
\hline$\ldots$ & filesharing & 25.00 \\
\hline$\ldots$ & forums & 58.04 \\
\hline$\ldots$ & GPS & 64.29 \\
\hline$\ldots$ & instant messenger & 59.82 \\
\hline$\ldots$ & web call & 22.32 \\
\hline$\ldots$ & learning platforms & 45.54 \\
\hline$\ldots$ & social media & 25.89 \\
\hline$\ldots$ & virtual reality & 90.18 \\
\hline$\ldots$ & webinar & 28.57 \\
\hline$\ldots$ & wiki & 60.71 \\
\hline NA & app & 3.57 \\
\hline$\ldots$ & audio and video recording & 3.57 \\
\hline$\ldots$ & augmented reality & 3.57 \\
\hline$\ldots$ & blog & 3.57 \\
\hline$\cdots$ & $\begin{array}{l}\text { e-learning and web-based } \\
\text { training }\end{array}$ & 3.57 \\
\hline$\ldots$ & e-portfolio & 3.57 \\
\hline$\ldots$ & filesharing & 3.57 \\
\hline$\ldots$ & forums & 3.57 \\
\hline$\ldots$ & GPS & 3.57 \\
\hline$\ldots$ & instant messenger & 3.57 \\
\hline$\ldots$ & web call & 3.57 \\
\hline ... & learning platforms & 3.57 \\
\hline$\ldots$ & social media & 3.57 \\
\hline$\ldots$ & virtual reality & 3.57 \\
\hline$\ldots$ & webinar & 3.57 \\
\hline$\ldots$ & wiki & 3.57 \\
\hline
\end{tabular}

\section{References}

1. WBGU-Wissenschaftlicher Beirat der Bundesregierung Globale Umweltveränderungen. Unsere Gemeinsame Digitale Zukunft: Zusammenfassung, 1st ed.; Wissenschaftlicher Beirat der Bundesregierung Globale Umweltveränderungen: Berlin, Germany, 2019; Available online: https://www.wbgu.de/fileadmin/user_upload/wbgu/publikationen/hauptgutachten/hg2019/pdf/WBGU_ HGD2019_Z.pdf (accessed on 21 December 2021).

2. Sun, P.C.; Tsai, R.J.; Finger, G.; Chen, Y.Y.; Yeh, D. What Drives a Successful E-Learning? An Empirical Investigation of the Critical Factors Influencing Learner Satisfaction. Comput. Educ. 2008, 50, 1183-1202. [CrossRef]

3. Keller, J.; Suzuki, K. Learner motivation and E-learning design: A multinationally validated process. J. Educ. Media 2004, 29, 229-239. [CrossRef] 
4. Margaryan, A.; Bianco, M.; Littlejohn, A. Instructional quality of Massive Open Online Courses (MOOCs). Comput. Educ. 2015, 80, 77-83. [CrossRef]

5. Park, J.-H.; Choi, H.J. Factors Influencing Adult Learners' Decision to Drop Out or Persist in Online Learning. Educ. Technol. Soc. 2009, 12, 207-217.

6. IPCC. Climate Change 2021: The Physical Science Basis; Contribution of Working Group I to the Sixth Assessment Report of the Intergovernmental Panel on Climate Change, Masson-Delmotte, V.P., Zhai, A., Pirani, S.L., Connors, C., Péan, S., Berger, N., Caud, Y., Chen, L., Goldfarb, M.I., Gomis, M., Eds.; Cambridge University Press: Cambridge, UK, 2021; Available online: https://www.ipcc.ch/report/ar6/wg1/ (accessed on 21 December 2021).

7. Sterling, S. Learning for resilience, or the resilient learner? Towards a necessary reconciliation in a paradigm of sustainable education. Environ. Educ. Res. 2010, 16, 511-528. [CrossRef]

8. UNESCO. Education for Sustainable Development Goals_Learning Objectives; UNESCO: Paris, France, 2017; Available online: https://www.unesco.de/sites/default/files/2018-08/unesco_education_for_sustainable_development_goals.pdf (accessed on 21 December 2021).

9. Deutsche UNESCO Kommissione. Bonner Erklärung 2014: UN-Dekade mit Wirkung-10 Jahre Bildung für Nachhaltige Entwicklung in Deutschland; Deutsche UNESCO Kommission: Bonn, Germany, 2014.

10. Rieckmann, M.; Stoltenberg, U. Partizipation als Zentrales Element von Bildung für Eine Nachhaltige Entwicklung. In Nachhaltige Gesellschaft: Welche Rolle für Partizipation und Kooperation? Heinrichs, H., Kuhn, K., Newig, J., Eds.; VS Verlag für Sozialwissenschaften, Springer Fachmedien Wiesbaden GmbH: Wiesbaden, Germany, 2011; pp. 117-131.

11. Köller, O.; Hasselhorn, M.; Hesse, F.W.; Maaz, K.; Schrader, J. (Eds.) Das Bildungswesen in Deutschland: Bestand und Potenziale; UTB Pädagogik; Julius Klinkhardt: Bayern, Germany, 2019; Bd. 4785.

12. Michelsen, G.; Rode, H.; Wendler, M.; Bittner, A. Außerschulische Bildung für Nachhaltige Entwicklung. Eine Bestandsaufnahme am Beginn des 21. Jahrhunderts; DBU-Umweltkommunikation; Oekom: München, Germany, 2013; Volume 1, Available online: http:/ / fox.leuphana.de/portal/de/publications/ausserschulische-bildung-fur-nachhaltige-entwicklung(f6d6e00d-b6af4052-a8d7-e5ddc031ea97).html (accessed on 21 December 2021).

13. Grundmann, D. Bildung für Nachhaltige Entwicklung in Schulen Verankern; Springer Fachmedien: Wiesbaden, Germany, 2017.

14. Butterer, H.; Wohnig, A. Kooperationen zwischen schulischer und außerschulischer politischer Bildung. Polis 2019, 23, 7-10. [CrossRef]

15. Beer, K.; Biedenkopf, K.; Breitmeier, H.; Gerner, M.; Große, N.; Gumbert, T.; Hein, J.; Hickmann, T.; Kiesler, N.; Lederer, M.; et al. Digital Sustainability Education-Potential, Development Trends and Good Practices; Universitätsbibliothek Gießen: Gießen, Germany, 2021.

16. Leiner, D.J. SoSci Survey, version 3.1.06; SoSci Survey GmbH: Munich, Germany, 2019; Available online: https: / / www.soscisurvey de (accessed on 21 December 2021).

17. Heumann, C.; Schomaker, M. ; Shalabh. Introduction to Statistics and Data Analysis—With Exercises, Solutions and Applications; Springer: Berlin/Heidelberg, Germany, 2016.

18. James, G.; Witten, D.; Hastie, T.; Tibshirani, R. An Introduction to Statistical Learning: With Applications; Springer: Berlin/Heidelberg, Germany, 2013

19. Eid, M.; Gollwitzer, M.; Schmitt, M. Statistik und Forschungsmethoden; Beltz: Weinheim, Germany, 2015.

20. R Core Team. R: A Language and Environment for Statistcal Computing; R Foundation for Statistical Computing: Vienna, Austria, 2018; Available online: https:/ / www.R-project.org/ (accessed on 21 December 2021).

21. Microsoft Corporation. Microsoft Excel; Microsoft: Redmond, WA, USA, 2018; Available online: https://office.microsoft.com/excel (accessed on 21 December 2021).

22. Overwien, B. Umweltbildung und Bildung für Nachhaltige Entwicklung. In Handbuch Politische Bildung, 4th ed.; Wolfgang, S., Ed.; Wochenschau-Verlag: Schwalbach am Taunus, Germany, 2014; pp. 375-382.

23. Lockley, J.; Jarrath, M. The Nature of Sustainability as Viewed by European Students. J. Educ. Sustain. Dev. 2013, 7, 113-124. [CrossRef]

24. Schreiber, J.-R. Bildung für Nachhaltige Entwicklung. In Handlexikon Globales Lernen; Lang-Wojtasik, G., Klemm, U., Eds.; Klemm \& Oelschläger: Münster, Germany; Ulm, Germany, 2012; pp. 26-30.

25. Asbrand, B.; Scheunpflug, A. Globales Lernen. In Handbuch Politische Bildung, 4th ed.; Wolfgang, S., Ed.; Wochenschau-Verlag: Schwalbach am Taunus, Germany, 2014; pp. 401-412. 